\title{
HYDROLOGICAL ANALYSIS IN WATER BASINS
}

\author{
ROCHA, Paulo Cesar; ${ }^{\text {* }}$ SANTOS, Aline Aparecida dos; ${ }^{\mathrm{b}}$
}

(a) Phd in Environmental Sciences. Paulista State University (UNESP), Presidente Prudente (SP) Brazil.. ORCID ID: https://orcid.org/0000-00021187-1093. CURRICULUM LATTES: http://lattes.cnpq.br/4346506814865509

(b) Mastering in Geographi of Paulista State University (UNESP), Presidente Prudente (SP) Brazil. CURRICULUM LATTES: http://lattes.cnpq. $\mathrm{br} / 7622794720439343$

\section{(*) CORRESPONDING AUTHOR}

Address: UNESP: Roberto Simonsen Street, 305, CEP: 19060-900, Presidente Prudente (SP) Brazil. Tel. (55) 18-3229-5388.

\section{ABSTRACT}

This work addresses the hydrological behavior in the basins of the Aguapeí and Peixe rivers, which drain part of the region of the Western Plateau of São Paulo state, Brazil. The spatial variation of the water production per unit area in the hydrographic basins was evaluated, taking as a reference different hydrological periods of the historical series of data. To this end, the hydrological regime of the rivers and the drainage area associated to the sampling stations were considered. The obtention of the fluviometric regime and hydrological periods were based on daily, monthly and annual data of historical series. The average specific flow rate was determined by the ratio between the average flow rate in a given measurement section and the respective drainage area. The results reveal changes in the spatial patterns of Qe. The stations located in the upper basin of the basins had a greater data variability in the three hydrological periods, which was expected. The increase in specific water production in certain hydrological periods can intensify the laminar and linear erosion processes, which may be an additional problem for areas with inadequate land management.

Keywords: Hydrological Variability; Hydrological zoning; Specific flow; Peixe River.

\section{RESUMO / RESUME}

\section{ANÁLISE HIDROLÓGICA EM BACIAS HIDROGRÁFICAS}

Este trabalho aborda o comportamento hidrológico nas bacias dos rios Aguapeí e Peixe, que drenam parte da região do Planalto Ocidental Paulista, Brasil. Foi avaliada a variação espacial da produção hídrica por unidade de área nas bacias hidrográficas, tomando-se como referencia diferentes períodos hidrológicos da série histórica de dados. Para tanto, foram considerados o regime hidrológico dos rios e a área de drenagem associada às estações de amostragem. A obtenção do regime fluviométrico e períodos hidrológicos foram baseados em dados diários, mensais e anuais de séries históricas. O índice de vazão específica média foi determinado pela razão entre a vazão média em uma dada seção de medição e a respectiva área de drenagem. Os resultados revelam alterações nos padrões espaciais da Qe. As estações situadas no alto curso das bacias apresentaram maior variabilidade nos dados nos três períodos hidrológicos, o que era esperado. $\mathrm{O}$ aumento da produção específica hídrica em determinados períodos hidrológicos pode intensificar os processos erosivos laminares e lineares, o que pode ser um problema a mais para áreas de manejo inadequado da terra.

Palavras chaves: Variabilidade Hidrológica; Zoneamento hidrológico; Vazão específica; Rio do Peixe.

\section{ANÁLISIS HIDROLÓGICO EN CUENCAS HIDROGRÁFICAS}

Este trabajo aborda el comportamiento hidrológico en las cuencas de los ríos Aguapeí y Peixe, que drenan parte de la región del Planalto Occidental Paulista, Brasil. Se evaluó la variación espacial de la producción hídrica por unidad de área en las cuencas hidrográficas, tomando como referencia diferentes períodos hidrológicos de la serie histórica de datos. Para ello, se consideraron el régimen hidrológico de los ríos y el área de drenaje asociada a las estaciones de muestreo. La obtención del régimen fluviométrico y períodos hidrológicos fueron basados en datos diarios, mensuales y anuales de series históricas. El índice de flujo específico promedio se determinó por la razón entre el caudal medio en una sección de medición y la respectiva área de drenaje. Los resultados revelan cambios en los patrones espaciales de la Qe. Las estaciones situadas en el alto curso de las cuencas presentaron mayor variabilidad en los datos en los tres períodos hidrológicos, lo que se esperaba. El aumento de la producción específica hídrica en determinados períodos hidrológicos puede intensificar los procesos erosivos laminares y lineales, lo que puede ser un problema más para áreas de manejo inadecuado de la tierra.

Palabras claves: Variabilidad Hidrológica; Zonificación hidrológica; Caudal específico; Río del Peixe. 


\section{INTRODUCTION}

River basins can be considered as physical systems where the input is the volume of precipitated water and the output is the volume of water drained at the outlet of the River Basin. In general terms, they are a well-defined physical unit for hydrological studies, having a single input, which is precipitation, and output is given by the runoff at the outlet of the basin, taking into consideration evapotranspiration losses. On the macro scale, as in the case of large hydrographic basins, the patterns of runoff, intensity and seasonality may be controlled primarily by climatic effects. This general pattern reflects the patterns of precipitation and general circulation of the atmosphere. However, aspects of the physical environment and land cover interact with each other to determine the natural seasonal and spatial pattern of runoff variation (PETTS \& FOSTER, 1990).

The runoff (discharge) is usually based on the monthly average discharges and allows the evaluation of the seasonality of the flows. The maximum and minimum annual average may reveal possible variations throughout the historical series of the season. These assessment aspects become important due to the interactions between man and the environment, the results of which usually promote changes in the aspects of intensity and quality of the precipitation-discharge relation in the river basin.

Knowledge about the hydrological regime of rivers is basic information for decision making in several areas of knowledge, especially for scholars interested in issues related to environmental planning and the use of water resources within the river basin. However, a lack of information usually makes it difficult to obtain such knowledge. The lack of data and the need to know them throughout the study area often prevent planning from being compatible with the needs of the area of interest.

On the other hand, with Federal Law No. 9,433 of January 8th, 1997, there was a greater control over the use of resources based on its regulation. The need to determine hydrological variables to be used in the management of water resources was established (SILVA JUNIOR, 2003), and the river basin has been used as a unit for the management of water resources.

In the study of water resources, the hydrographic basin can be considered, in general terms, as a physical system where the input of water is the volume precipitated and the output is the volume of water drained by the river mouth and the evapotranspiration. Generally speaking, it provides a well-defined physical unit for hydrological studies, having a single input, precipitation, and output is given by runoff at the river mouth, considering evapotranspiration losses. On the macro scale, as in the case of large hydrographic basins, the pattern of the runoff and its intensity and seasonality may be controlled, primarily, by climatic effects. This general pattern reflects the patterns of precipitation and general circulation of the atmosphere. To compare individual river basins, the geology, basin morphometry, soils and vegetation, as well as climatic aspects, interact with each other to determine the natural seasonal pattern of variation in runoff (PETTS \& FOSTER, 1990).

The variability of the hydrological regime is controlled by several elements that characterize the hydrographic basin, such as lithology, relief, soils, vegetation cover and also by climatic factors such as precipitation, solar radiation and evaporation (TUCCI, 2002). For Clarke et al. (2003), factors such as geographic location and / or altitude may contribute substantially to the results of flow regime analysis, air mass advancement, local precipitation events, among others.

Although the control of hydrological systems is greater in developed countries, the inadvertent modifications in these systems are universal, generally as a function of the present model of the appropriation of nature by contemporary man. Human interventions in the hydrological cycle can occur in different phases. The hydrological cycle functions as a series of water storage (water tanks), connected by transfers. Some of these deposits or boxes are present as such because of the speed of transfers, which may be slower (e.g. underground) or faster (e.g. rivers), which may also have a limited storage function. At each point of intervention in these locations different impact intensities may occur (DREW, 1994). 
In general, the greatest impacts are associated with the relation between infiltration-flow, due to interference in vegetation, soil and river flows (ROCHA \& ANDRADE, 2012). In the short term, the loss of tree cover reduces the loss of soil water by transpiration, as the deep roots of the trees are cut off, as well as causing more water flow on the surface of the land, since the old vegetation and the cushioning blanket of fallen leaves are replaced by bare soil or by crops with lower storage potential. Thus, the likelihood of the direct flow of water to the rivers is increased. Figure 1 illustrates the effect of deforestation on the river flow of small river basins (DREW, 1994).
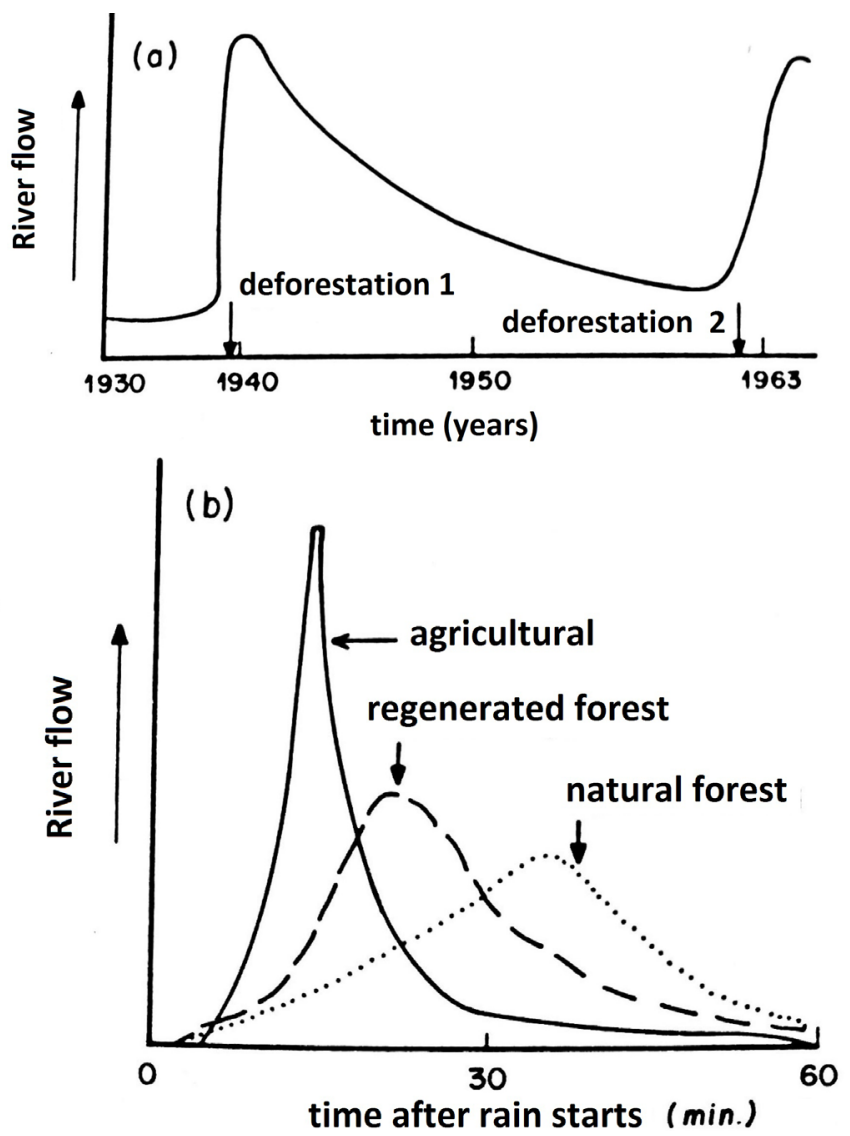

Figure 1 - Effects of deforestation on the flow of a river. In (a) change of river flow after deforestation. In (b) the different hydrographs after rainfall in basins of the same area with different uses of the soil Source: Drew (1994).

Water production in a river basin depends on several climatic factors such as precipitation, humidity, evaporation, temperature, winds etc. (TUCCI \& CLARK, 1998). Topography is also an important influence on rainfall production (ANDRIUCCI et al., 2002). These in turn directly influence the surface and underground flow, depending on the flow velocity. Specifically, regarding hydrological studies, precipitation corresponds to the water coming from evaporation that returns to the surfaces in different forms, contributing to the volumes of water in the rivers and reservoirs.

The mean specific flow rate is a hydrological variable that can be used in studies of hydrological regionalization or zoning. It is determined by the ratio between the mean flow rate in a given measurement section and the respective drainage area (TUCCI, 2002). This parameter should only be used in areas with a low density of fluviometric stations (LIMA et al., 2008), with the aid of GIS (Geographic Information System) software and geotechnologies for spatial representation and mapping. It serves as a measure of hydric production relative to different sized areas of a river basin.

The hydrological zoning of a river basin can serve as an important tool to visualize areas of similar behavior from the point of view of the use of surface water, in order to contribute to the planning and management of surface water resources. As well as the principles that govern environmental zoning, it aims at the balance of ecosystems and the sustainability of natural resources. 
Currently, the plans for the implementation of the charging policy for the use and concession of water resources in the scope of the Committee of Hydrographic Basins in the State of São Paulo are at different stages. However, there are still problems with monitoring, which is still lacking in fluvial courses; problems persist with public supply and the updating of regionalization maps.

This work presents a superficial hydrological study and refers to a parallel analysis to the analysis of traditional hydrological regionalization, with a comparative analysis of distinct hydrological periods. In this hydrological zoning, there is a geographic analysis of the spatial-temporal variations of the specific hydric production as a variable of the surface runoff, with the purpose of supporting the management bodies.

The objective of this study is to analyze the spatial variation of water production per unit area in the hydrographic basins of the Aguapeí and Peixe rivers, in the western region of São Paulo, taking as a reference different hydrological periods of the historical data series. The hydrological behavior of the rivers was analyzed along a historical series of about 70 years, using the hydrological periods identified in the regional literature, supported by statistical analysis of the time series, from the perspective of temporal and spatial dynamics. The intention is to understand the variations in the distribution of the specific flow in space and time, as a subsidy to the most severe public policies on the uses of water in this area by the official bodies.

\section{LOCATION OF THE STUDY AREA}

The hydrographic basins of the Aguapeí and Peixe rivers are located in the western portion of the state of São Paulo between the coordinates -49.395142; and -52.168376, west longitude and $-20.951768 ;-22.439189$, South latitude. Due to some similarities in the geographic, physical and socioeconomic aspects the Water Resources Management Units (UGRHI) of the Aguapeí (UGRHI 20) and Peixe Rivers (UGRHI 21) were included in a single Hydrographic Basin Committee, according to state law $n^{0} 7.663$ of December 30th, 1991. Both are managed by the Hydrographic Basin Committee of the Aguapeí and Peixe Rivers (CBH-AP).

According to CBH-AP (2013), the interdependence between these two river basins and those surrounding them is low, they have a greater interference with each other, although there are municipalities that have part of their area inside the limits of these basins, but are not part of them, since their municipal headquarters are located in slopes belonging to other hydrographic basins. Thus, these municipalities are denominated "integrants", and are mostly those located on the dividing line of these basins' hydrographs.

The incorporation of these basins into a single Committee was specifically aimed at promoting the discussion about the hydric issues inherent to the territory and the integration of the various actions and activities aimed at the recovery and preservation of water resources in the area $(\mathrm{CBH}-$ -AP, 2013).

Together, the UGRHI Aguapeí and Peixe have an area of approximately $21,167 \mathrm{~km}^{2}$, composed of fifty-nine (59) municipalities, as detailed in Andrade (2011). It has boundaries to the North with the Tietê River Basin, to the West with the State of Mato Grosso do Sul, having as its border the Paraná River, to the East with the Serra dos Agudos and to the South with the basin of the Paranapanema River (CBH -AP, 1997), as shown in figure 2.

According to Sant'Anna Neto (1995) the rainfall pattern in the state of São Paulo shows a downward trend from East to West and from South to North. Such variations are mainly influenced by the general circulation of the atmosphere, characterized by the action of the (continental and maritime) tropical masses. There is the direct influence of the northwest-southeast front that reaches the area of the Pontal do Paranapanema and the slopes facing the channel of the Paraná River. In this region, rainfall totals are around 1,100 and 1,500 $\mathrm{mm}$ annually, considered the lowest in the state. 


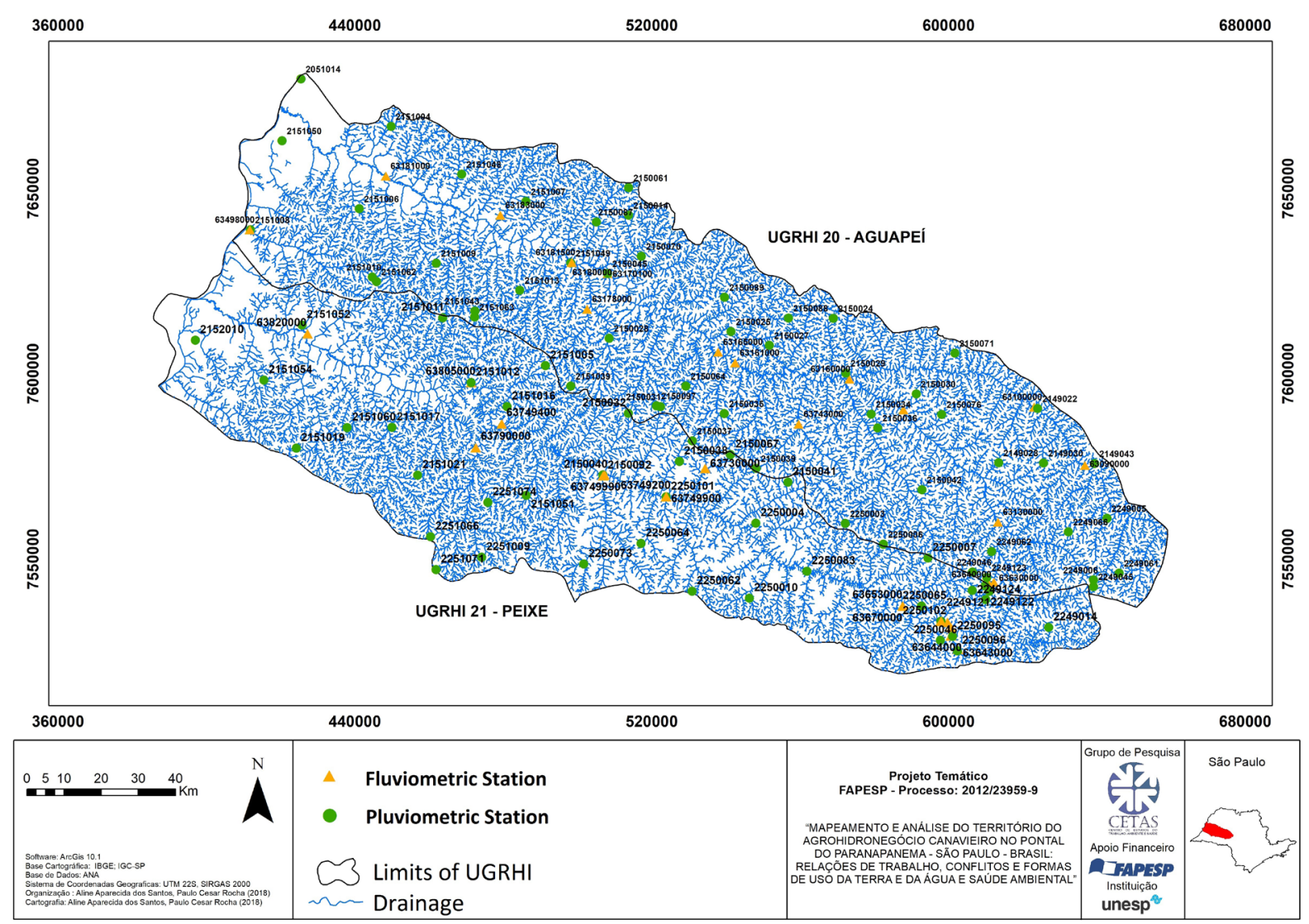

Figure 2 - Location of the study area and location of fluviometric stations and rainfall stations in the hydrographic basins of the Aguapeí and Peixe rivers.

Source: Andrade (2014)

The regional climate is influenced by air masses, such as Atlantic Tropical (Ta), Tropical Continental (Tc) and Continental Equatorial (Ec), alternating between a period with higher temperatures and high rainfall (from October to March) and another with mild temperatures and lower rainfall indexes (April to September) (SOUZA, 2005), as shown in Figure 3.

The normal annual isohyetal map (period 31-60) of the South American Climatic Atlas (WMO/ UNESCO, 1975, in ZAVATINI, op cit), shows that rainfall in the Paraná basin was between 1,200 and 1,600 mm, except in the extreme west of Mato Grosso do Sul (Pantanal), where values fell $(1,000 / 1,200 \mathrm{~mm})$; in the south-central part of Paraná, in the southwest of Minas Gerais and Goiás $(2,000 \mathrm{~mm})$ and in the upper Paraná River, where the weaker indices were between 800 and 1,000 $\mathrm{mm}$. According to this author, these characteristics practically maintained the same distribution in the period 1966/1985. 


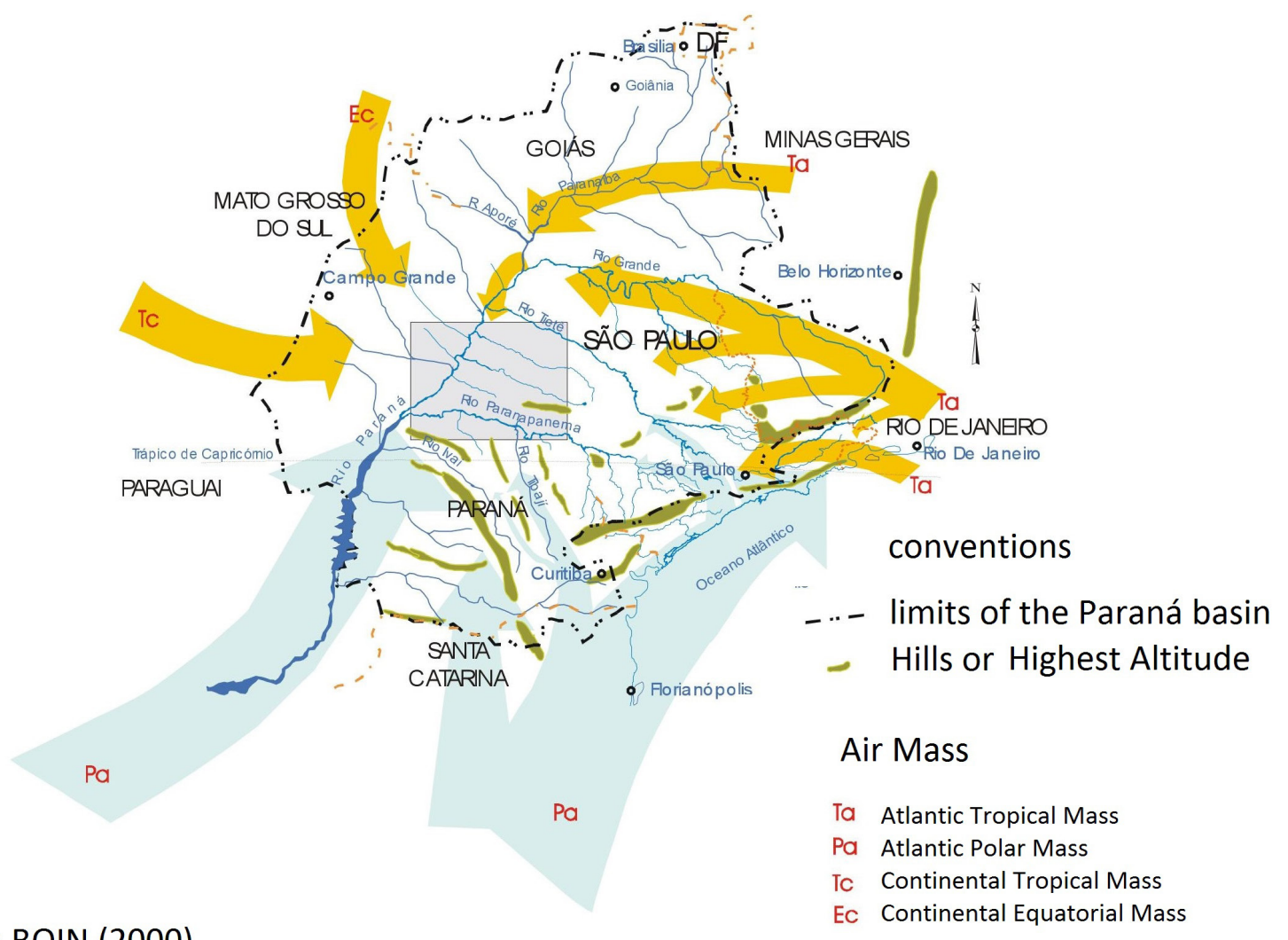

\section{Based in BOIN (2000)}

Figure 3 - Action of the air masses that influence the climate in the West of São Paulo and the study area. Source: Boin, (2000)

Figure 4 shows the annual rainfall totals of the historical series for a total of 46 (maximum value) stations located within the limits of the basins studied here, in the West of São Paulo.
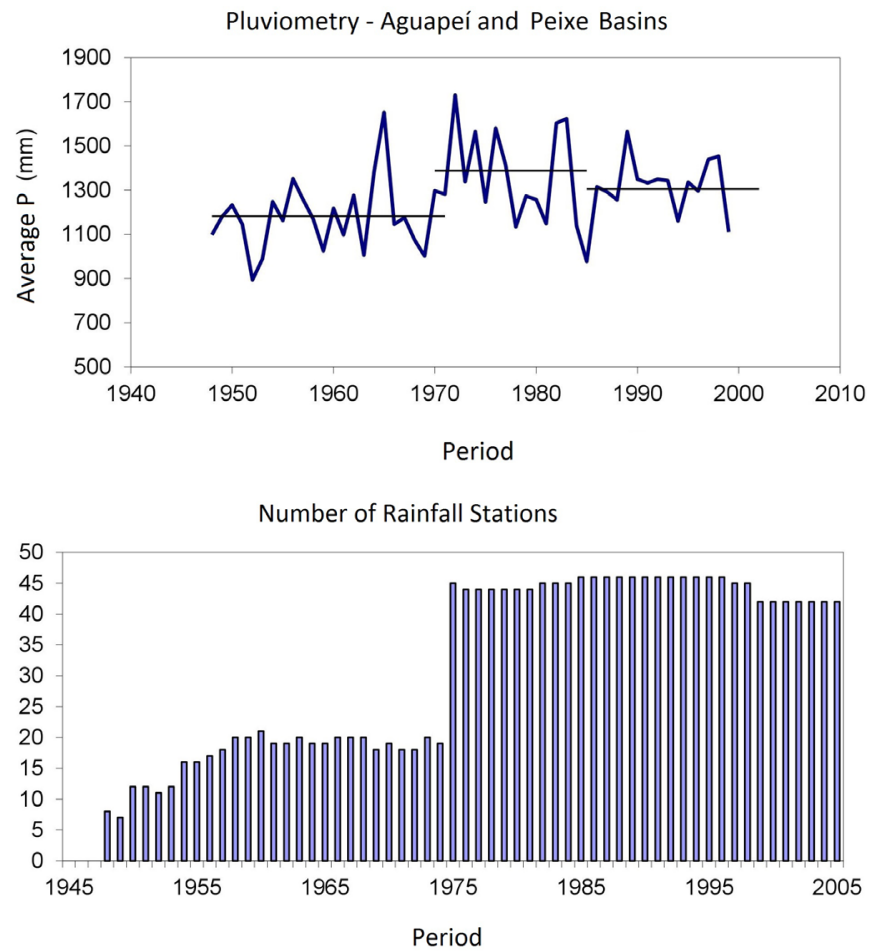

Figure 4 - Average annual total rainfall in the area of the basins of the Aguapeí and Peixe rivers, Oeste Paulista. A) Interannual variation and average of the identified periods; B) number of stations evaluated.

Source: Rocha \& Andrade (2015) 
Considering the total interannual values, the hydrological periods identified in the fluviometric data have a good visual correlation. It was also possible to perceive the different hydrological periods similar to those presented previously. The average values for the period 1947-1971 were 1,182 mm (1st period), 1972-1984 of 1,389 mm (2nd period) and 1985-2004 of 1,305 mm (3rd period).

Figure 5 presents a synthesis of the degradation potential based on the criticality of erosion processes in the two basins and their subdivisions. According to the general diagnosis of the Basin Plan (CBH-AP, 2008), many areas are found to have highly critical erosive processes, and thus have a high potential for degradation.

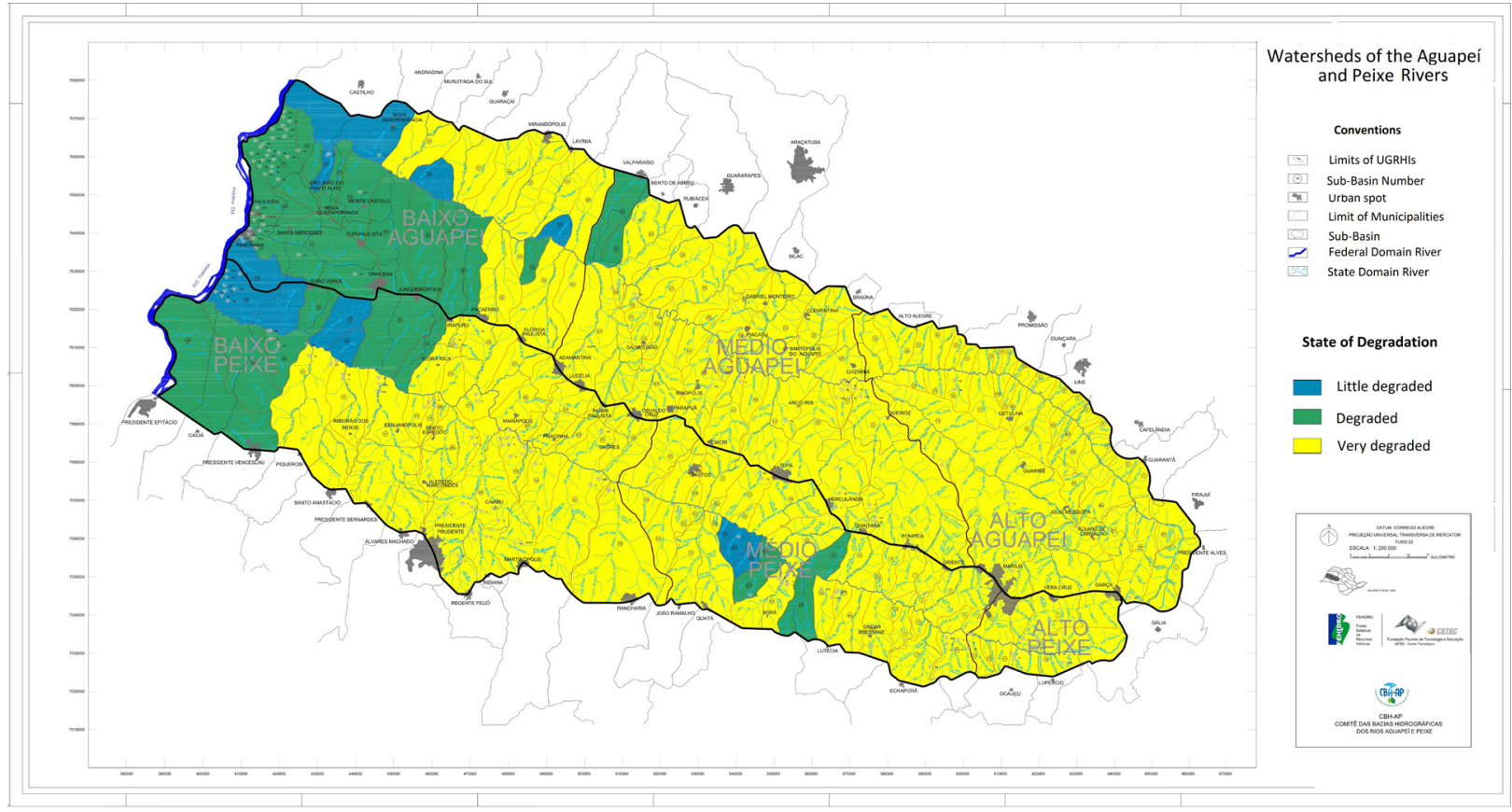

Figure 5 - Potential for degradation in the basins of the Aguapeí and Peixe rivers in the high, middle and lower sectors, according to the official division of UGRHIs 20 and 21

Source: CBH-AP (2008).

Due to sandy soil characteristics, associated with inappropriate land use, according to the Synthesis Book of the Hydrographic Basins of the Aguapeí and Peixe Rivers (CBH-AP, 2011), 70\% of the basin areas have a high degree of potential soil erosion. Figure 6 presents a study on erosive and depositional trends for the two water resources' management units.

It is evident that part of the upper basin presents a very high tendency to erosive and depositional processes. In general, however, a high tendency to erosive and depositional processes predominates from the upper to the middle courses of the basin. Only the lower courses of the Aguapeí and Peixe Rivers have a low tendency to erosion and deposition processes.

In general, the land use of both basins is dominated by pastures, with an intense advance of sugarcane as a temporary crop. The graphs in Figure 7 show the division of activities in the rural area, based on CBH-AP reports.

\section{PREVIOUS STUDIES OF THE HYDROLOGICAL REGIME OF RIVERS IN THE UPPER PARANÁ RIVER BASIN}

The investigations of the hydrological behavior of the rivers of the Upper Paraná basin to understand their hydrological variability and changes in the rivers' regime have been analyzed in several studies, such as Clarke et al. (2003), Tucci \& Clarke (1998) and Collischonn et al. (2001) on the Paraguay River, and by Rocha et al. (2010), Rocha (2010) on the Paraná River and Araujo 
(2011), Rocha e Araújo (2017) on the Paranapanema River. The latter are also associated with the effects of large dams. These studies have observed a distinct change in the magnitude of the hydrological regime of the rivers from the beginning of the 1970s. They have associated this alteration to the effect of the control of debits by the large dams in the basin and, in part, to the processes of use and occupation on the hillsides. In the West Paulista basins, recent studies of the Aguapeí and Peixe rivers have also indicated the existence of hydrological periods coinciding with the previously mentioned studies (ROCHA \& TOMMASELLI, 2012).
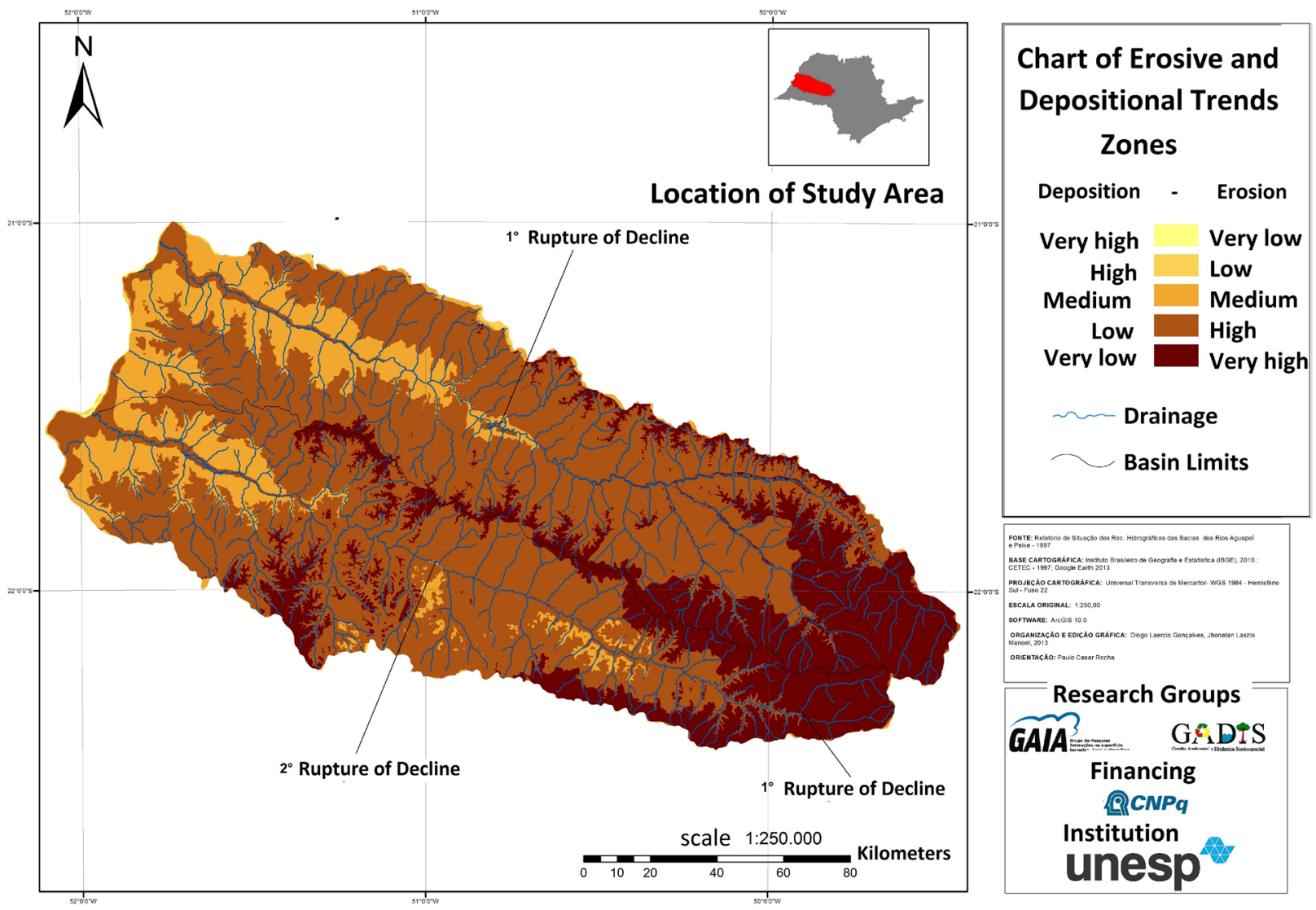

Figure 6 - Chart of zones of erosive and depositional trends of the Aguapeí and Peixe River Basins. Source: MANOEL (2015)
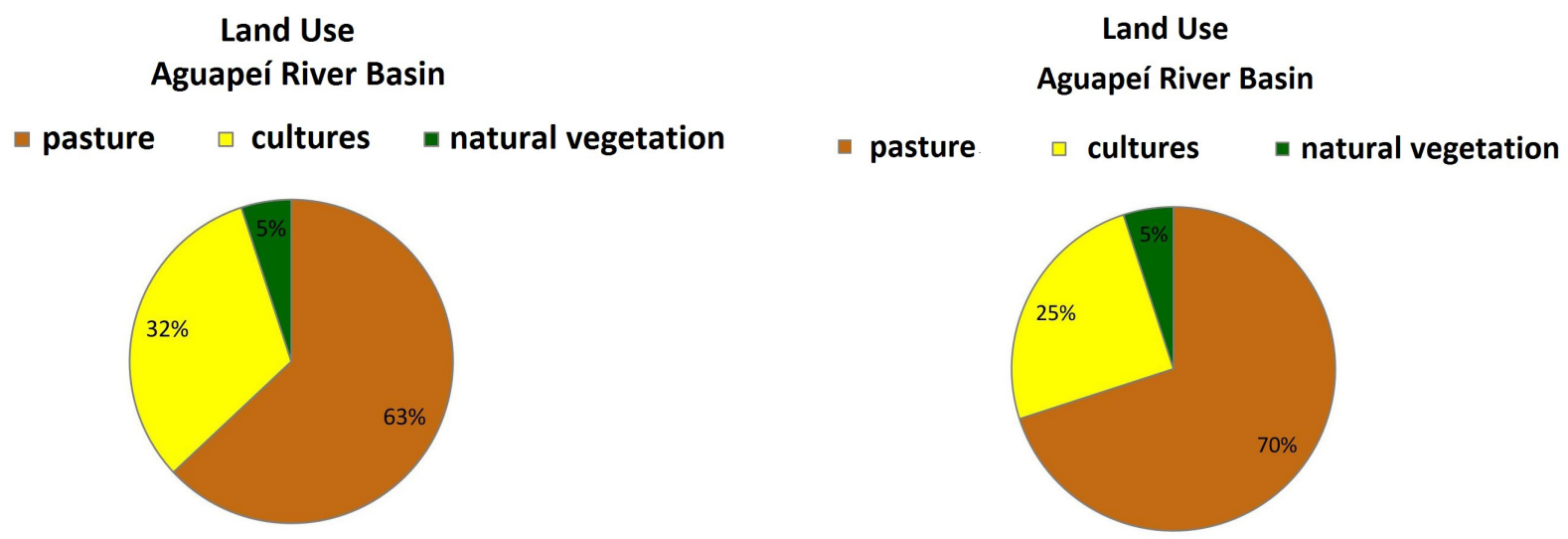

Figure 7 - Main land uses in UGRHIs 20 (Aguapeí River) and 21 (Peixe River). Source: SANTOS (2013). 


\section{PROCEDURES}

Fluviometric stations with long historical series in operation and / or having a long series of data until recently, were inventoried with a survey of the National Water Agency and the State Water Department of São Paulo / SIGRH. Subsequently, the location of the representative stations and the daily and monthly hydrological data were evaluated, seeking to contemplate the high, middle and lower sections of the main rivers in the two basins chosen for the analyzes.

It is important to remember that the two hydrographic units (Aguapeí and Peixe) are composed of drainage channels that run through lands of the same geological - the sandstones of the Bauru Group (IPT, 1981), and geomorphological domain - the western plateau of São Paulo (ROSS \& MOROZ, 1997). They also belong to the same climatic region - alternately dry and humid tropical climate (MONTEIRO, 1973), which facilitates the correlation between the data of the stations.

Thus, the approach used was the Index of Hydrological Change (AHI), proposed by Poff et al. (1997). This methodology is an important tool for the execution of public policies and decision making that allow the environmental recovery and sustainability of water courses. The index used was the Interannual Magnitude.

For stations with an incomplete historical series, the data were estimated by correlation (in this work established for R2 greater than 0.7) through a simple linear regression between stations within the same geographical area, as recommended by Poff et al. (1997) and Macdonald et al. (2008) (Table 1). For the calculation of the Specific Flow, the most representative stations in drainage area were selected for the Upper, Middle and Lower courses of the two basins (ANDRADE, 2014).

Table 1 - Characteristics of fluviometric stations with flow data in the Aguapeí and Peixe rivers (UGRHs 20 and 21 )

\begin{tabular}{|c|c|c|c|c|c|}
\hline Code & Place name & $\begin{array}{l}\text { Geographic Coordi- } \\
\text { nates }\end{array}$ & Municipality & Basin / River & Drainage area $\left(\mathrm{km}^{2}\right)$ \\
\hline 63100000 & Nova Fatima & $\begin{array}{l}21^{\circ} 46^{\prime} 49^{\prime \prime} \\
49^{\circ} 48^{\prime} 33^{\prime \prime}\end{array}$ & Guaimbe & Aguapeí & 1092 \\
\hline 63160000 & Bom Retiro Farm & $\begin{array}{l}21^{\circ} 42^{\prime} 52^{\prime \prime} \\
50^{\circ} 17^{\prime} 27^{\prime \prime}\end{array}$ & Luziânia & Aguapeí & 3670 \\
\hline 63165000 & Rinópolis / Piacatu & $\begin{array}{l}21^{\circ} 39^{\prime} 07^{\prime \prime} \\
50^{\circ} 38^{\prime} 14^{\prime \prime}\end{array}$ & Rhinopolis & Aguapeí & 6217 \\
\hline 63170100 & Salto Carlos Botelho & $\begin{array}{l}21^{\circ} 27^{\prime} 30^{\prime \prime} \\
50^{\circ} 552^{\prime} 0^{\prime \prime}\end{array}$ & Rubiacea & Aguapeí & 7668 \\
\hline 63180000 & Valparaiso / Adamantina & $\begin{array}{l}21^{\circ} 25^{\prime} 53^{\prime \prime} \\
51^{\circ} 00^{\prime} 54^{\prime \prime}\end{array}$ & Valparaiso & Aguapeí & 8643 \\
\hline 63650000 & S. Geraldo neighborhood & $\begin{array}{l}22^{\circ} 18^{\prime} 0^{\prime \prime} \\
50^{\circ} 2^{\prime} 0^{\prime \prime}\end{array}$ & Marília & Peixe & 734 \\
\hline 63670000 & Avencas / Oscar Bressani & $\begin{array}{l}22^{\circ} 16^{\prime} 00^{\prime \prime} \\
50^{\circ} 08^{\prime} 52^{\prime \prime}\end{array}$ & Echaporã & Peixe & 1061 \\
\hline 63710000 & Quatá Road & $\begin{array}{l}22^{\circ} 3^{\prime} 46^{\prime \prime} \\
50^{\circ} 36^{\prime} 34^{\prime \prime}\end{array}$ & Tupã & Peixe & 2883 \\
\hline 63810000 & Elora Rica / Emilianopolis & $\begin{array}{l}21^{\circ} 44^{\prime} 38^{\prime \prime} \\
51^{\circ} 26^{\prime} 41^{\prime \prime}\end{array}$ & Elora Rica & Peixe & 7422 \\
\hline 63700000 & Varpa & $\begin{array}{l}22^{\circ} 4^{\prime} 56^{\prime \prime} \\
50^{\circ} 32^{\prime} 58^{\prime \prime} \\
\end{array}$ & Tupã & Peixe & 2650 \\
\hline
\end{tabular}

Source: ANDRADE (2014).

In order to understand the interannual flow variability, the annual averages of the hydrological series of the stations available for these basins were used, which had been previously studied by Rocha \& Andrade $(2012,2015)$. The stations' interannual data were tabulated in spreadsheets and graphs of the historical series were elaborated, using a station in each basin, with the longest series of historical data. The identification of the periods was done from the visual analysis and then by a comparative statistical test of the means, standard deviation and coefficient of variation for validation. 
The average specific flow rate is determined by the ratio between the mean flow rate in a given measurement section and the respective drainage area (TUCCI, 2002). According to this author, the tendency is a reduction of the specific flow upstream to downstream, as the size of the basin and the length of the river increase.

In this sense, the hydrological zoning from the specific flow can also be used as a technique to improve the understanding and quality of the hydrological data. Thus, the average specific flow rate to be used in hydrological zoning is obtained by equation (1):

$$
\mathbf{Q}=\frac{\mathbf{Q}_{\mathrm{m}}}{\mathrm{A}}
$$

Where:

Qe, is the average specific flow in Ls-1.km-2;

Qm, is the average monthly flow converted to Ls-1;

$\mathrm{A}$, is the area of influence in the hydrographic basin in $\mathrm{km}^{2}$.

The data and hydrological zoning obtained were presented through the spatial analysis of the fluviometric stations used in the study, considering three stretches of the basins, according to the position of the stations in the upper, middle and lower courses of the main rivers.

\section{RESULTS AND DISCUSSION}

\section{THE INTERANNUAL AND SEASONAL VARIABILITY OF THE AGUAPEÍ AND PEIXE RIVERS AND HYDROLOGICAL PERIODS.}

The hydrological regime of the two rivers under study can be observed in figure 8 and table 1. There have been changes in the interannual magnitudes of the two rivers since the beginning of the 1970s, similarly to the Paraná and Paraguay rivers. The differential for the Paraná River is that it still shows a flattening of the maximum and minimum peaks since the beginning of the 1970s, which are attributed to flow control by the damns upstream (UHEs) that coincidently started operating from this period onwards. The data of the two basins evidences that they have similar hydrological behaviors.

However, not only two hydrological periods were observed, but at least three, considering the data series used. A first period until 1972; another between 1972 and 1984; the third from 1985. It is still likely that this last period or hydrological phase will end in 2001 when a new hydrological period may have begun, but the data series evaluated do not allow better detailing.

Analyzing the graphs in figure 5 and the data in table 1, we can see that the two rivers have the same hydrological behavior, corroborating the premise that they belong to the same climatic and hydrological region in the West of São Paulo.

The analysis of the graph results indicates three clearer hydrologic periods (ROCHA \& ANDRADE, 2012). The first is characterized by lower magnitudes of the flow and a lower interannual variability. They have smaller values for the magnitude of the flow, standard deviation and coefficient of variation than the values of the complete data series.

The second period is characterized by higher flow magnitudes and a greater interannual variability. The results show higher values of the average flow magnitude, standard deviation and coefficient of variation than the data of the complete series.

The third period is marked by proximity to the mean values for the previous period, but with 
a lower variance. The mean flow values were also higher than the mean of the complete series, but with lower values of standard deviation and coefficient of variation. In this period, the lowest values of the coefficient of variation were observed, considering the complete historical series and the individual periods.

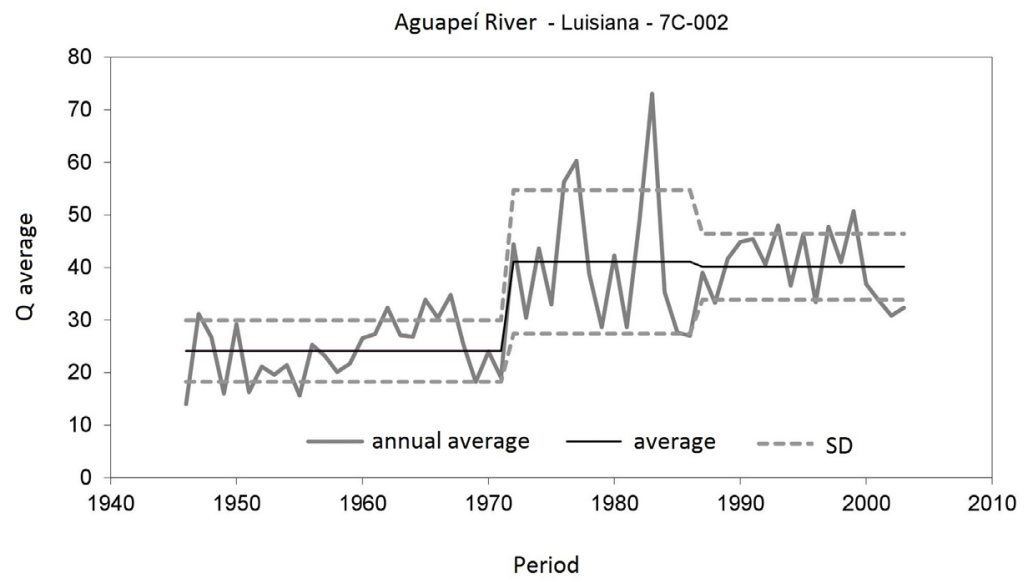

Peixe River - Tupã - 63710000

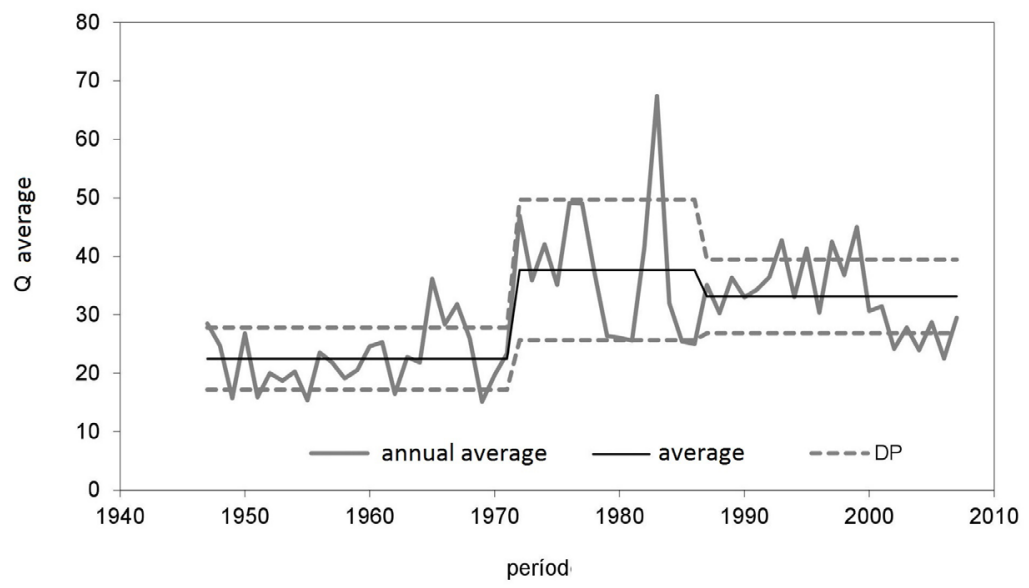

Figure 8 - Graphs showing the variability of the annual mean flows and hydrological periods identified in two representative stations of the basins of the Aguapeí (A) and Peixe (B) rivers.

Source: ROCHA AND ANDRADE (2012).

Thus, in terms of flow variability, the standard deviations and coefficients of variation calculated indicate that the interannual variability of the flow had a much greater intensity in the second hydrological period, which covers 1972-1984 (table 2).

Regarding the seasonal variations, these have higher values in the last two periods observed (1972-1984, 1985-2004). The mean monthly variability was similar between the second and third periods. Seasonal mean flow values were lower in the first period than in the others for all the stations evaluated in the two rivers. Like the interannual data, the seasonal behavior in the two basins is similar, which corroborates the understanding that the two basins belong to a homogeneous region in terms of physical and environmental environment. 
ROCHA, P. C.; SANTOS, A. A. dos

Table 2 - Statistical parameters applied to the data series of the fluviometric stations evaluated in the basins of the Aguapeí and Peixe rivers. The data obtained from the values of the annual average of historical series between the decades of 1940 and 2004. Qm (average annual flows, $\mathrm{m}^{3} . \mathrm{s}-1$ ); SD (standard deviation of the series); CV (coefficient of variation in\%). Hydrological periods identified: 1 (1947-1971), 2 (1972-1984), 3 (1985-2004).

\begin{tabular}{|c|c|c|c|c|c|}
\hline Aguapeí River & 63100000 & 63160000 & 63165000 & 63170100 & 63180000 \\
\hline Qm 1948-1971 & 7.17 & $25 / 11$ & 42.92 & $51(68 \%)$ & 54.97 \\
\hline Qm 1972-1984 & 12.71 & 41.62 & 71.37 & 86.96 & 95.38 \\
\hline Qm 1985-2004 & 11.56 & 38.78 & 65.90 & 77.60 & 82.92 \\
\hline$\sigma \quad 1948-1971$ & 2.01 & 6.26 & 9.35 & 11.24 & 23.66 \\
\hline$\sigma \quad 1972-1984$ & 4.84 & 13.42 & 20.25 & $02 / 23$ & 30.85 \\
\hline$\sigma \quad 1985-2004$ & 2.6 & 7.16 & 11.42 & 12.84 & 20.73 \\
\hline CV 1948-1971 & 27.98 & 24.94 & 21.78 & 41.17 & 23.66 \\
\hline CV 1972-1984 & 38.09 & 32.25 & 28,37 & 24.47 & 30.85 \\
\hline $1985-2004 \mathrm{CV}$ & 22.44 & 18.46 & 17.33 & 27.42 & 20.73 \\
\hline Peixe River & 63650000 & 63670000 & 63710000 & 63700000 & 63810000 \\
\hline Qm 1948-1971 & 6.15 & 11.80 & 24.66 & $21: 52$ & 66.37 \\
\hline Qm 1972-1984 & 9.71 & 15.29 & 39.52 & 32.01 & 98.89 \\
\hline Qm 1985-2004 & 8.98 & 12.32 & 32.28 & 28,26 & 80.26 \\
\hline$\sigma \quad 1948-1971$ & 1.46 & 2.62 & 6.22 & 5.0 & 9.67 \\
\hline$\sigma \quad 1972-1984$ & 3.40 & 4.78 & 12.09 & 11.0 & 18.93 \\
\hline$\sigma \quad 1985-2004$ & 2.33 & 2.50 & 6.39 & 4.03 & 10,18 \\
\hline CV 1948-1971 & 23.67 & 22.17 & 25.20 & 23.29 & 17.05 \\
\hline CV 1972-1984 & 34.98 & 31,23 & 30,6 & 34.28 & 23.68 \\
\hline $1985-2004 \mathrm{CV}$ & 25.99 & 20.28 & 19.8 & 14.26 & 14.52 \\
\hline
\end{tabular}

It can also be observed that the second period (1972-1984) had a greater irregularity in the seasonality of the flow, especially in the dry season, as shown in figure 9.
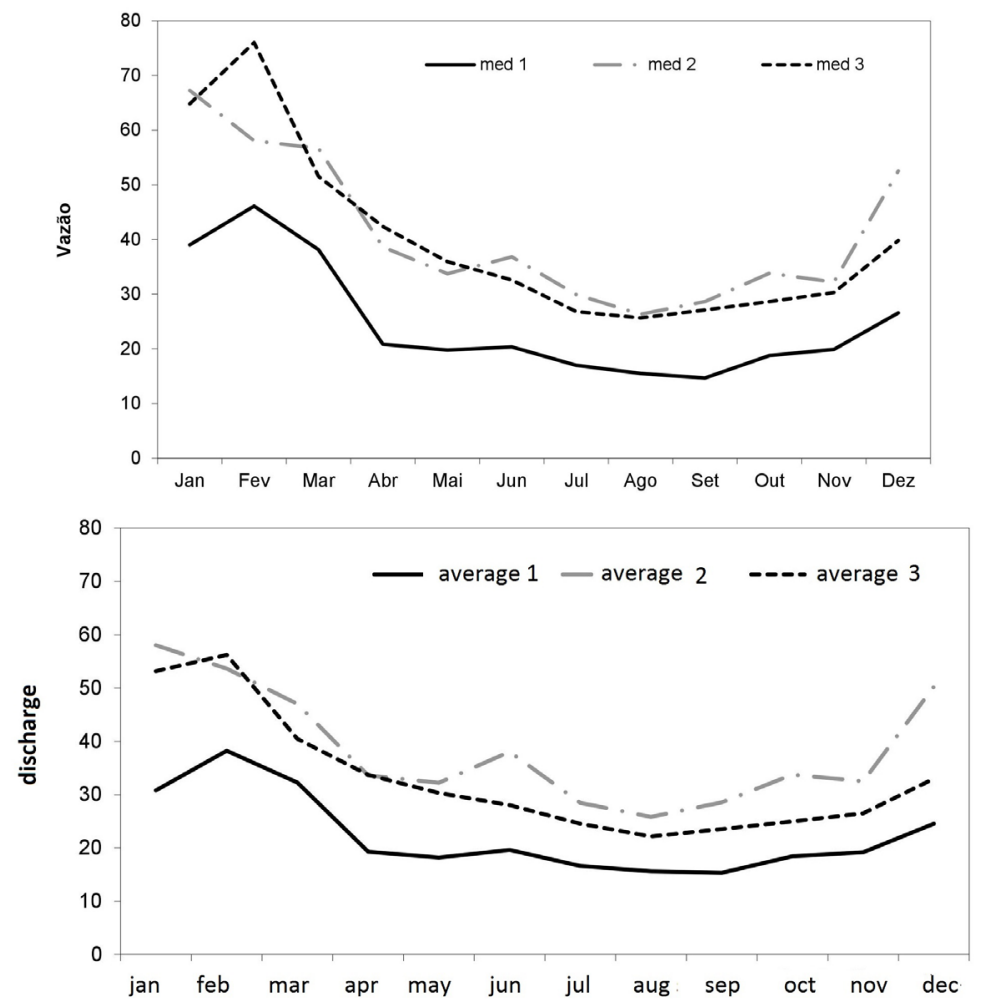

Figure 9 - Statistics of seasonal variations along the historical series and hydrological periods identified. 1, 2 and 3 are the periods referred to in the table 1 statement. A) basin of the Aguapeí river (63160000); B) Peixe river basin

(63710000). Source: ROCHA AND ANDRADE (2012). 
When comparing the periods 1941/1970 and 1971/1993, Sant'Anna Neto (2000) observed a trend of increased rainfall in the State of São Paulo, of approximately $10 \%$ in the second period, concentrated in the limits of the Paraná basin. A small increase in rainfall values and seasonal rainfall change was observed in the region of Presidente Prudente-SP, in the West of São Paulo, from the 1970s.

Even considering the possibility of an average increase in rainfall in the Paraná basin, this fact alone may not explain the set of changes that occurred in the hydrological regime of the rivers, as in the case of the Paraná River over the last century, demonstrated by Rocha (2010). However, if this possibility is true, it may be that the changes related to the magnitude of the fluviometric indices are partially in line with this tendency and are added to the effects of the use and occupation of the slopes, causing changes in the hydrological regime of the rivers of the West.

Changes in the intensity and seasonality of rains observed by Rocha \& Tommaselli (2012) are also related to the above-mentioned hydrological periods. The authors noted that summers became more humid and the wettest month shifted from December-January to February-March over the decades. On the other hand, they observed an intensification of the dry period, also with the shift of the driest months to the winter and spring, which had previously been more humid. Other data associated with the atmospheric dynamics in the southern hemisphere also point to the alternation of wetter and drier cycles (associated with hotter and colder periods, respectively), as pointed out by Molion (2008) based on the Pacific Decadal Oscillation).

\section{THE AVERAGE SPECIFIC FLOW (QE) IN THE BASINS OF THE AGUAPEÍ AND PEIXE RIVER}

Using the statistical relationships obtained between the Average Flow and the Drainage Area in different segments of the Drainage Basins under study, it was possible to identify how the spatial relationship was established along the historical series and considering the observed hydrological periods. Thus, using statistical relationships and model equations by hydrographic basin, the application in Figure 10 shows significant differences in the specific water availability between the hydrological periods. It is noted that in the first hydrological period the estimated flow values were well below those of the second and third periods for the different sizes of the drainage area (Figure 10). On the other hand, there are similarities in the behavior between the two drainage basins. 


\begin{tabular}{cccc} 
A) BACIA DO RIO AGUAPEI & \multicolumn{3}{c}{ U meala } \\
\hline Area $\left(\mathrm{km}^{2}\right)$ & 1 per & 2 per & 3 per \\
\hline 1 & 0.01 & 0.01 & 0.02 \\
10 & 0.07 & 0.13 & 0.16 \\
100 & 0.66 & 1.22 & 1.38 \\
1000 & 6.65 & $11 / 69$ & 11.68 \\
3,000 & 19.96 & $34: 40$ & 32.39 \\
6000 & 39.95 & 67.96 & 61.63 \\
10,000 & 66.61 & 112.25 & 99.02 \\
15000 & 99.96 & 167.17 & 144.26 \\
\hline B) BACIA DO RIO DO PEIXE & Q média & \\
\hline Area $\left(\mathrm{km}^{2}\right)$ & 1 per & 2 per & 3 per \\
\hline 1 & 0.01 & 0.02 & 0.01 \\
10 & 0.11 & 0.15 & 0.08 \\
100 & 1,00 & 1.41 & 0.89 \\
1000 & 9.25 & 13.51 & 10.16 \\
3,000 & 26.68 & 39.74 & 32.41 \\
6000 & 52.08 & 78.49 & 67.39 \\
10,000 & 85.25 & 129.63 & 115.57 \\
15000 & 126.05 & 193.02 & 177.34 \\
\hline & & &
\end{tabular}

Figure 10 - Estimated flow data and regression equations for the Aguapeí and Peixe river basins in the identified hydrological periods.

Source: Adapted from ANDRADE (2011)

Considering each of the hydrological periods identified, the results point to a significant increase in the Qe in the second period (1972-1984), and in the third period (1985-2004) the values remained close, but a little lower (Table 3, Figure 10-A). However, there was a gradual decrease in the variability of Qe over the periods, indicating a better spatial adjustment in the Qe. These data indicate that there was a greater homogeneity of values between basin stations, as the hydrological periods occurred (Table 3, Figure 10-B). This shows a better adjustment between the Qe and the area of the stations over time (figure 10).

In terms of average variation by sector, the largest variations of Qe values were observed in the stations of the lower course, between the first and second and between the second and third hydrological periods.

Table 3 - Average specific flow (Qe) calculated according to hydrological periods in the basins of the Aguapeí and Peixe rivers (Qe in Ls-1.km-2).

\begin{tabular}{lcccc}
\hline \multicolumn{2}{c}{$\begin{array}{c}\text { Drainage Area }\left(\mathbf{k m}^{2}\right) \\
\text { Qe 1947-1971 }\end{array}$} & \multicolumn{3}{c}{ Hydrological periods } \\
& 734 & 8.38 & 13.23 & 12.23 \\
Upper Course & 1061 & 11.12 & 14,41 & 11.61 \\
& 1092 & 6.57 & 11.64 & 10.59 \\
& 2650 & 8,12 & $12 / 08$ & 10.66 \\
Middle Course & 2883 & 8.55 & 13.71 & 11.20 \\
& 3670 & 6.84 & 11.34 & 10.57 \\
& 6217 & 6.90 & $11: 48 \mathrm{AM}$ & 10,60 \\
& 7422 & 8,94 & $13-32$ & 10.81 \\
Lower Course & 7660 & 6.78 & 11.54 & 10.13 \\
Station Averages & $8643)$ & 6.36 & 11.04 & 9.59 \\
DP dist. space & & 7.86 & 12.38 & $10.80-$ \\
CV dist. space & & 1.48 & 1.18 & 0.74 \\
\hline
\end{tabular}

SD: Standard Deviation; CV: Coeficient of Variation 
According to Tucci (2002), there is a tendency of a reduction in the specific flow from upstream to downstream, depending on the size of the basin and the length of the river.

The smallest spatial differences were observed between High, Middle and Lower course in the basins between the first and third periods. This situation allows the inference that the spatial differences in the Qe between the High, Middle and Lower river sectors decreased in the space from the first to the second hydrological period, with a higher water volume in the system. In absolute terms, the largest variations in the Qe occurred in the high-water sector in the Aguapeí river basin (63100000) between the second and the first period and between the third and second hydrological periods, indicating a more intense response to variations in the volume of water available to river flow. In general, there is still a greater homogeneity between the spatial sectors in the third hydrological period, in relation to the others, and a greater heterogeneity in the first hydrological period (Figure 10-B).
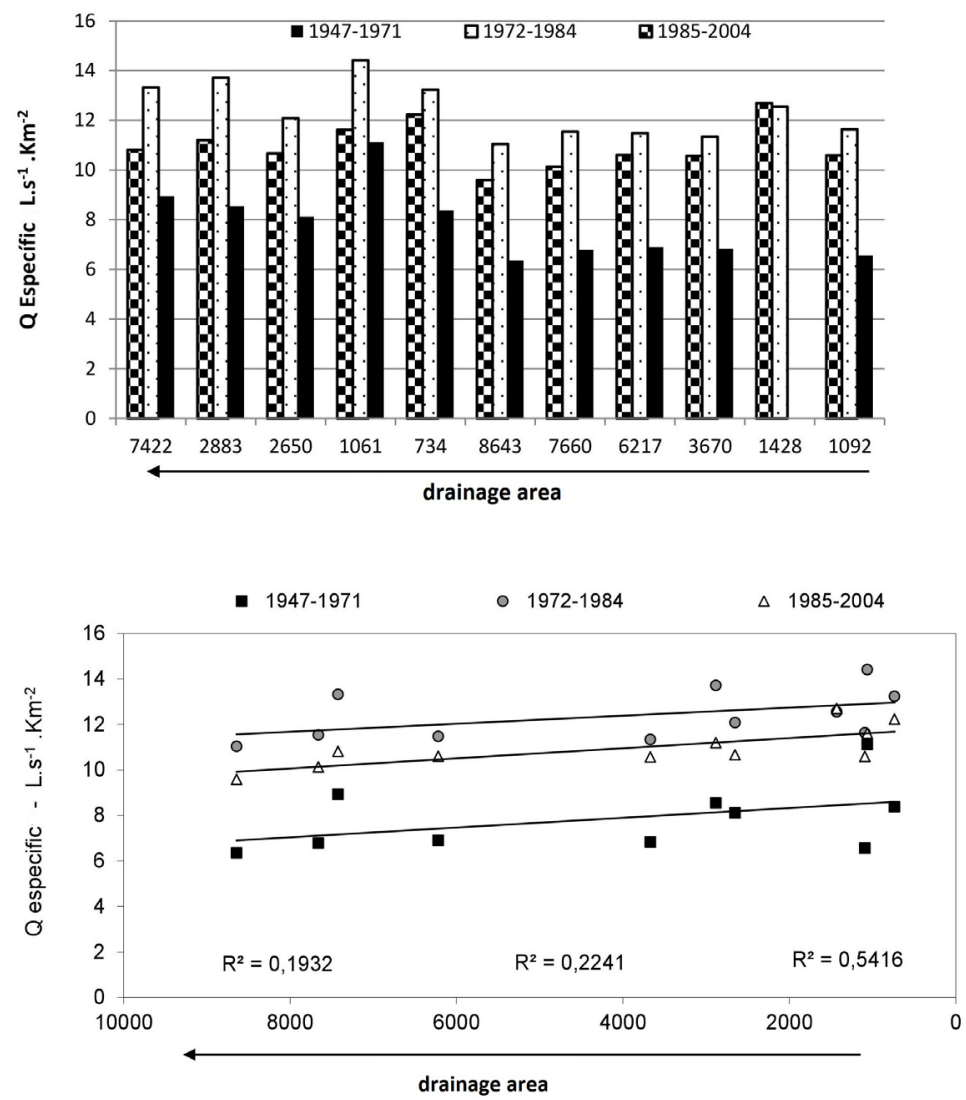

Figure 11 - Graphical representation of the temporal and spatial variation of the average specific flow in the basins of the Aguapeí and Peixe rivers.

Source: Rocha \& Andrade (2015).

\section{FINAL CONSIDERATIONS}

In this study it is possible to observe the existence of different hydrological periods produced by the natural climatic variability, with a duration of about 10 to 20 years in each period, corroborating the results of previous researches in the region, which indicate the existence of several hydrological periods throughout the last century and the beginning of the present one. This study also corroborates the affirmation of previous studies in the catchment area of the Upper Paraná River regarding the increase of river flows from the 1970s.

The identification of changes in the natural flow regime can be an efficient tool in the decision making regarding strategies to mitigate the impacts on the adjacent (eco) systems. It is also important in the identification of the patterns of climatic variability and relationships with the 
processes triggered on the slopes (use and occupation) or in the hydrographic network itself (such as in hydroelectric operations and public supply).

In general, the two drainage basins had very similar behavior, which reaffirms the idea that they are in a homogeneous physical and environmental region, leading them to behave in a similar manner.

The results reveal changes in the spatial patterns of Qe. The stations located in the upper courses of the basins had more variable data in the three hydrological periods, which was expected. As for the temporal patterns, the first period had a greater variability in the values between the high, middle and lower courses. There was a gradual increase in the homogeneity of the values between the basin stations, as the hydrological periods happened.

The interannual changes in the hydrological regime of the rivers are reflected by two components: 1) rainfall variability (climatic), as a natural process in the time scale evaluated; 2) anthropic interference altering the land cover, with the processes of deforestation and implementation of several cycles of crops and livestock over time, qualitatively and quantitatively modifying the hydrological relation at the rainfall - river flow interface. The data are not conclusive for a statement on climate change.

In the specific case of the west of São Paulo, coffee / cotton, pasture and sugar cane cycles may have influenced the patterns of variation and characterization of the hydrological periods observed and deserve a more detailed approach in the future.

The increase of specific water production in certain hydrological periods can intensify the laminar and linear erosive processes, which can be a problem for areas with inadequate land management.

The results also reveal that, under intense demand, the existence of hydrologic periods with more or less surface water availability should be considered in legal procedures for water grants. Such considerations may prevent potential conflicts. There is a need for a study of an efficient methodology to predict hydrological periods of less water availability and legally determined strategies of action.

The first step in the right direction for water resource planning is to incorporate studies (understanding) of river flow regimes and their changes into management strategies and to recognize that change may be imposed on river flow by human actions and result in problems of public supply and sanitation, in addition to intense geomorphic and ecological changes in these systems.

\section{ACKNOWLEDGEMENTS}

The authors thank the CNPq for the financial support of the research project, process: 408444 / 2013-4, Call 43/2013 - Human, Social and Applied Social Sciences; and to FAPESP for the granting of scholarship, proc. 2012 / 06637-8.

\section{BIBLIOGRAPHIC REFERENCE}

ANDRADE, L. F. Análise espaço-temporal do escoamento fluvial nas bacias hidrográficas dos rios aguapeí e peixe, oeste paulista, Brasil. Dissertação (Mestrado em Geografia) - Faculdade de Ciências e Tecnologia, Universidade Estadual Paulista, Presidente Prudente-SP, 2014.

ANDRIUCCI, L. R.; SANT'ANNA NETO, J. L.; FERREIRA, M. E. M. C., 2002. Análise da variabilidade e tendência das chuvas e a descrição da produção agrícola na Bacia do rio Pirapó - PR. Boletim de Geografia, v. 20 p. 214-57, 2002.

ARAUJO, A. P. Dinâmica fluvial e regime hidrológico na bacia hidrográfica do rio Paranapanema. 166f. Dissertação (Mestrado em Geografia) - Faculdade de Ciências e Tecnologia, Universidade Estadual Paulista, Presidente Prudente-SP, 2011.

BOIN, M. N. Chuvas e erosões no Oeste Paulista. 264 f. Tese (Doutorado em Geociências e Meio Am- 
biente) - Instituto de Geociências e Ciências Exatas, Universidade Estadual Paulista, Rio Claro, 2000. COMITÊ DAS BACIAS HIDRIGRÁFICAS DOS RIOS AGUAPEÍ E PEIXE, 1997. Relatório Zero. Disponível em: http://cbhap.org/publicacoes/pbh/. Acessado em 21 de jul. 2013.

COMITÊ DAS BACIAS HIDRIGRÁFICAS DOS RIOS AGUAPEÍ E PEIXE. Plano das bacias dos rios aguapeí e peixe. Caderno Síntese das Bacias dos Rios Aguapeí e Peixe, CBH-AP. Marília-SP, 2008. Disponível em: http://cbhap.org/publicacoes/pbh/. Acesso em 15 de agosto de 2015.

COMITÊ DAS BACIAS HIDROGRÁFICAS DOS RIOS AGUAPEÍ E PEIXE. Relatório de Situação dos recursos hídricos. Marília-SP. Disponível em: http://cbhap.org/publicacoes/pbh//. Acessado em 21 de jul. 2013.

COLLISCHONN, W, TUCCI, C.E.M. \& CLARKE, R.T. Further evidence of changes in the hydrological regime of the Paraguay River: part of a wider phenomenon of climate change?. Journal of Hydrology 245, 218-238, 2001.

CLARKE, R. T.; TUCCI, C. E.; COLLISCHONN, W. Variabilidade temporal no regime hidrológico da bacia do rio Paraguai. Revista Brasileira de Recursos Hídricos. Vol. 8 n. 1 jan mar p. 201-211, 2003.

DREW, D. Processos interativos homem-meio ambiente. Bertrand Brasil. 3a. ed. Rio de Janeiro, 1994.

HANNAH, D. M.; BOWER, D.; MCGREGOR, G. R. Associations between Western European air-masses and river flow regimes. Climate Variability and Change - Hydrological Impacts. Fifth Friend World Conference held at Havana, Cuba, IAHS Publ. 308, 2006.

IEMMA, A. F. Estatística descritiva. Piracicaba: Phi Sigma Ro Publicações. 1992, 182p.

IPT - INSTITUTO DE PESQUISAS TECNOLÓGICAS DO ESTADO DE SÃO PAULO. Mapa geológico do Estado de São Paulo; escala 1:500.000. v1 (texto) e v2 (mapa), 1981. Governo do estado de São Paulo. Secretaria da Indústria, Comércio, Ciência e Tecnologia.

KINGSTON, D. G.; LAWLER, D. M.; MACGREGOR, G. R. Linkages between atmospheric circulation, climate and streamflow in the northern North Atlantic: research prospects. Progress in Physical Geography, v. 2 n. 30 , p. $143-174,2006$.

LIMA, J. E. F. W.; SILVA, E. M.; SILVA, F. A. M.; SANO, E. E. Variabilidade espaço-temporal da vazão específica média no Estado de Goiás. In: Simpósio Internacional de Savanas Tropicais. II, 2008, Brasília: Anais... p 1-6, 2008.

MACDONALD, N. PHILLIPS I.D. Reconstructed annual precipitation series for Scotland (1861-1991). In: Spatial and temporal variations and links to the atmospheric circulation. Scot Geographical Journal, p.122: 1-18, 2006.

MACDONALD, N., PHILLIPS I.D \& THORPE, J., 2008. Reconstruction of long-term precipitation records for Edinburgh: an examination of the mechanisms responsible for temporal variability in precipitation. Theor. Appl. Climatol., p. 141-154, 2008.

MANOEL, J.L. Interação os perfis longitudinais dos Rios Aguapeí e Peixe, paramêtros morfomêtricos e morfologia das vertentes nas bacias hidrográficas. 80f. TCC (Graduação em Geografia) - Faculdade de Ciências e Tecnologia, Universidade Estadual Paulista, Presidente Prudente-SP, 2015.

MELLER, A., ALLASIA. D., COLLISCHONN, W.; TUCCI, C. E. M. Sensibilidade do regime hidrológico de Bacias hidrográficas à variabilidade da precipitação. Revista Brasileira de Recursos Hídricos, 5, pp. 13-34, 2005.

MENARDI JUNIOR, A. Regime e ritmo das chuvas na Bacia do Rio Piracicaba. 291f. Tese de Doutorado - Universidade Estadual Paulista, Instituto de Geociências e Ciências Exatas, Rio Claro, São Paulo, 2000.

MOLION, L.C.B. Perspectivas climáticas para os próximos 20 anos. Revista Brasileira de Climatologia. ABClima. Vol. 2/4 , ano 4. Presidente Prudente-SP, 2008.

MONBEIG, P. Pioneiros e Fazendeiros de São Paulo. Ed. Hucitec. Sao Paulo. 1984, 392p.

MONTEIRO, C.A.F. A dinâmica climática e as chuvas do estado de São Paulo: estudo geográfico sob forma de atlas. São Paulo: IGEOG, 1973.

PETTS, G. \& FOSTER, I. Rivers and Landscape. The Athenaeum Press, 3 ed., New Castle, Great Britain, 1990. 
POFF, H.L., ALLAN, D., BAIN, M.B., KARR, J.R., PRESTEGAARD, K.L., RICHTER, B.D., SPARKS, R.E., \& STROMBERG, J.C. The natural flow regime: a paradigm for river conservation and restoration. Bioscience, vol. 47, n. 11. p. 769-784, 1997.

REYNARD, N. S.; PRUDHOMME, C.; CROOKS, S. M. The flood characteristics of large U.K. Rivers: Potential effects of changing climate and land use. Climate change, n 48, p 343-349, 2001.

RICHTER, B.D., BAUMGARTNER, J.V., POWELL, j \& BRAUN, D.P. A method for assessing hydrologic alteration within ecosystem. Conservation Biology, 10-4, 1163-1174p, 1996.

RICHTER, B.D., BAUMGARTNER, J.V., WIGINGTON, R. \& BRAUN, D.P. How Much Water Does a River Need. Freshwater Biology, 37. 231-249 p, 1997.

ROCHA, P.C. Indicadores de alteração hidrológica no alto rio Paraná: intervenções. Sociedade \& Natureza, Uberlândia, 22 (1): 205-225, 2010.

ROCHA, P. C. \& ANDRADE, L. F. O regime interanual de rios na região oeste de São Paulo (Brasil). In: Universidade de Coimbra-PT. (Org.). Para conhecer a terra. 1ed. Coimbra, Portugal: ed da Univers Coimbra, v. 1, p. 351-358, 2012.

ROCHA, P.C.; FERNANDEZ, O.V.Q.; SOUZA FILHO, E.E. Influência de Grandes Barragens Sobre o Regime Hidrológico do Rio Paraná em Guaíra-PR. In: An. $5^{\circ}$ Cong. Bras. de Geógrafos, Curitiba-PR. Boletim de resumos, 1994.

ROCHA, P.C., SOUZA FILHO, E.E \& FERNANDEZ, O.V.Q., 1998. Aspectos do controle de descargas efetuado por barramentos no alto rio Paraná. Boletim Paranaense de Geociências, 46. Curitiba-Pr-Brasil, p 117-122, 1998.

ROCHA, P.C., SANTOS, M.L. \& SOUZA FILHO, E.E. Alterações no regime hidrológico do alto rio Paraná como resposta ao controle de descargas efetuado por grandes barramentos a montante. In: VIII Encuentro de Geógr. de América Latina, Santiago-Chile, p 28-39, 2001.

ROCHA, P.C., SOUZA FILHO, E.E \& COMUNELLO, E. Considerações sobre a variabilidade hidrológica do alto rio Paraná. Revista GeoUERJ, Rio de Janeiro, 2003.

ROCHA, P.C. \& TOMMASELLI, J. T. G. Variabilidade hidrológica nas bacias dos rios aguapeí e peixe, região Oeste Paulista. Rev Brasileira de Climatologia. n 8, v. 10, p 69-84, 2012.

ROCHA, P. C., HOOKE, J. M. \& MORAIS, E.S. The interannual regime of rivers: a comparison between Peixe river (western of São Paulo state, Brazil) and Dee river (Snowdonia, UK). In: 8 IAG International Conference on Geomorphology, Paris, France, 27-31/8, 2013.

ROSS, J. L. S.; MOROZ, I. C. Mapa geomorfológico do Estado de São Paulo. Revista do Departamento de Geografia, São Paulo, n.10, p.41-56, 1996.

SANT'ANNA NETO, J.L., 2000. As Chuvas no Estado de São Paulo: A Variabilidade Pluvial nos Últimos 100 Anos. In: SANT'ANNA NETO, J.L. \& Zavatini, J.A. (orgs). Variabilidade e Mudanças Climáticas. Eduem, Maringá-PR, 2000.

SANTOS, A. A. Dinâmica Hidrossedimentológica nos Rios Aguapeí e Peixe, Oeste Paulista. 74f. TCC (Graduação em Geografia) - Faculdade de Ciências e Tecnologia, Universidade Estadual Paulista, Presidente Prudente-SP, 2013.

SILVA JÚNIOR, O. B.; BUENO, E. O.; TUCCI, C. E . M.; CASTRO, M. N. R. Extrapolação Espacial na Regionalização da Vazão. Revista Brasileira de Recursos Hídricos. v. 8 n.1 Jan/Mar, 21-37p, 2003.

SILVEIRA, A., MOURA, R. M. P., ANDRADE, N. R.L. Determinação da Q7,10 para o rio Cuiabá, Mato Grosso, Brasil e comparação com a vazão regularizada após a Implantação do reservatório de aproveitamento múltiplo de manso. In: XXX Congreso Interamericano De Ingeniería Sanitaria Y Ambiental. Punta del Este - Uruguay, 2006.

TUCCI, C.E.M \& CLARKE, R.T. Environmental Issues in the la Plata Basin. Water resources development, 4 (2), 157-173, 1998.

TUCCI, C. E. M. Regionalização de vazões. Rio Grande do Sul: Ed. Universidade/UFRGS, 2002. p.14.

ZAVATINI, J.A. Anos Secos e Anos Chuvosos na Bacia do Paraná. In: IX Encontro Sul-Mato-Grossense de Geógrafos. Três Lagoas-MS, 1998. 